\title{
Non-radioactive dot-blot DNA reassociation for unequivocal yeast identification
}

\author{
Gianluigi Cardinali, Gianni Liti and Alessandro Martini
}

Dipartimento di Biologia Vegetale-Sezione Microbiologia Applicata, Borgo 20 Giugno 74, I-06121 Perugia, Italy
Author for correspondence: Gianluigi Cardinali. Tel: +3975585 6478. Fax: +3975 5856470 . e-mail: gianlu@unipg.it

\begin{abstract}
Unequivocal and rapid classification of yeast cultures cannot be accomplished exclusively on the basis of unstable phenotypic traits, but requires molecular tests relating to the whole genome (or the largest possible portion of it). DNA-DNA reassociation meets this requirement, although many procedures proposed for calculating overall sequence similarity are expensive and timeconsuming, thus restricting the possibility of unequivocal classification to a few specialized laboratories. A novel method, based on non-radioactive dotblot hybridization of whole genomic DNA, has shown high and reproducible proportionality between the detected signal and the amount of doublestranded DNA effectively present on the membrane. This procedure has been optimized to obtain, within two working days, DNA relatedness values between unknown cultures and the type strains of the species previously indicated by a few conventional tests. The effective ability of the method to discriminate strains belonging to different species has been tested within taxonomic models consisting of yeast type cultures already certified by spectrophotometric reassociation.
\end{abstract}

Keywords: yeast, taxonomy, dot blot, reassociation, classification

\section{INTRODUCTION}

Conventional yeast taxonomy is based on the qualitative analysis of a series of morpho-physiological traits supposedly capable of enabling discrimination between species. These phenotypic data can be analysed with either a hierarchical approach (Kurtzman \& Fell, 1998) or a numerical approach (Barnett et al., 1990; Lockhart, 1967); in both cases, however, an unequivocal species determination is rarely obtained. Nuclear DNA reassociation is widely considered to be the test of choice for unequivocal assignment of unknown strains to known species (Bak \& Stenderup, 1969; Dutta et al., 1967; Guého et al., 1985; Kurtzman, 1990a, b, 1986; Meyer, 1970; Meyer \& Phaff, 1972; Ouchi et al., 1970; Springer \& Krajewski, 1989; Vaughan-Martini, 1991). This approach calls for a comparison between the nDNAs from both the unknown culture and the type strain of the species previously indicated by conventional classification. Several procedures have been proposed to measure the level of DNA renaturation (Hara et al., 1991), including the spectrophotometric evaluation of reannealing kinetics (Kurtzman et al., 1983; Lee et al., 1993; Martini \& Phaff, 1973; van der Walt \& Johannsen, 1979; Vaughan-Martini, 1991) and radio- active hybridization on nitrocellulose filters (Meyer et al., 1975, 1977; Ouchi et al., 1970). The former method requires large amounts of DNA and a dedicated spectrophotometer equipped with an expensive thermoprogrammer and is also time-consuming (being barely capable of comparing more than two strains in one working day). The radioactive method is potentially hazardous, requires a scintillation counter and is unable to compare DNAs from more than one culture on the same membrane. To overcome the above limitations, a different reassociation method that is rapid and suitable for comparing large numbers of strains is necessary, especially for biodiversity, taxonomy, ecology and evolution studies (all of which require unequivocal specific assignment).

In this paper, a novel, non-radioactive DNA-DNA reassociation method for screening several samples simultaneously, and requiring only $100 \mathrm{ng}$ DNA per compared yeast, is proposed.

\section{METHODS}

Cultures and growth. The yeast cultures reported in Table 1 and Table 2 were obtained from the Industrial Yeasts Collection (DBVPG), Perugia, Italy. Cells for DNA extraction were grown at $25^{\circ} \mathrm{C}$ in shaken (150 r.p.m. $\left.\mathrm{min}^{-1}\right)$ 
Table 1. Quality of regression curves calculated between the optical densities of the dots and the quantities of DNA from different yeast species

$R^{2}$ values higher than 0.99 indicate good correlation between the DNA content in the dots and the signal obtained.

\begin{tabular}{|lcl|}
\hline Species & $\begin{array}{c}\text { DBVPG } \\
\text { no.* }\end{array}$ & $\boldsymbol{R}^{\mathbf{2}}$ value \\
\hline Debaryomyces prosopidis & $7010^{\mathrm{T}}$ & $0 \cdot 9971$ \\
Hanseniaspora vinae & $6792^{\mathrm{T}}$ & $0 \cdot 9663$ \\
Hanseniaspora uvarum & $6717^{\mathrm{T}}$ & $0 \cdot 9742$ \\
Hanseniaspora guilliermondii & $6796^{\mathrm{T}}$ & $0 \cdot 9331$ \\
Hanseniaspora osmopila & $6791^{\mathrm{T}}$ & $0 \cdot 9930$ \\
Mean ... & & $\mathbf{0 . 9 8 4 7}$ \\
Standard error... & & $\mathbf{0 \cdot 0 0 6 0}$ \\
\hline
\end{tabular}

* $\mathrm{T}$, Type strain.

Table 2. DNA content spotted on the dots represented in Fig. 2

\begin{tabular}{|lllr|}
\hline Sample & \multicolumn{1}{c}{ Species } & $\begin{array}{c}\text { DBVPG } \\
\text { no. }^{*}\end{array}$ & $\begin{array}{c}\text { DNA } \\
\text { content } \\
\text { (ng) }\end{array}$ \\
\hline A & Kluyveromyces delphensis & $6073^{\mathrm{T}}$ & 100 \\
$\mathbf{B}$ & Kluyveromyces lactis & 6031 & 100 \\
$\mathbf{C}$ & Kluyveromyces lactis & 6731 & 100 \\
$\mathbf{D}$ & Kluyveromyces wickerhamii & $6077^{\mathrm{T}}$ & 100 \\
$\mathbf{E}$ & Kluyveromyces lactis & 6108 & 100 \\
$\mathbf{F}$ & Saccharomyces cerevisiae & $6173^{\mathrm{T}}$ & 100 \\
$\mathbf{G}$ & Kluyveromyces lactis (probe) & $6305^{\mathrm{T}}$ & 20 \\
$\mathbf{H}$ & Kluyveromyces lactis (probe) & $6305^{\mathrm{T}}$ & 40 \\
$\mathbf{I}$ & Kluyveromyces lactis (probe) & $6305^{\mathrm{T}}$ & 60 \\
$\mathbf{J}$ & Kluyveromyces lactis (probe) & $6305^{\mathrm{T}}$ & 100 \\
\hline
\end{tabular}

*T, Type strain.

bottles $(500 \mathrm{ml})$ containing $50 \mathrm{ml}$ YEPD $(1 \%$ yeast extract, $1 \%$ Bacto-peptone, $2 \%$ dextrose; Difco).

DNA extraction and preliminary purification. Overnight YEPD cultures $\left(14 \mathrm{ml}\right.$, containing approx. $1 \times 10^{8}$ cells $\mathrm{ml}^{-1}$ ) were transferred to $15 \mathrm{ml}$ polypropylene capped tubes and centrifuged for $2 \mathrm{~min}$ at $2000 \mathrm{~g}$. Cell pellets were washed with $10 \mathrm{ml}$ distilled water, spun again and resuspended in $0.4 \mathrm{ml} 120 \mathrm{mM}$ Lysis buffer $(0.5 \%, \mathrm{w} / \mathrm{v}, \mathrm{SDS} ; 0.5 \%$, w/v, Sarkosyl in TE, $\mathrm{pH} 7.5$ ) in the presence of $0.4 \mathrm{ml} 0.5 \mathrm{~mm}$ diameter acid-washed glass beads and $0.4 \mathrm{ml}$ of a solution containing $50 \%$ of Tris-equilibrated $(\mathrm{pH} 8.0)$ phenol and $50 \%$ chloroform. After $5 \mathrm{~min}$ at $-18{ }^{\circ} \mathrm{C}$, the suspension was bead-beaten (1500 r.p.m.) at room temperature for $3 \mathrm{~min}$; this operation was repeated after a 2 min interval at $-18^{\circ} \mathrm{C}$. The supernatant obtained after a $10 \mathrm{~min}$ centrifugation at $2000 \boldsymbol{g}(0 \cdot 5-0 \cdot 6 \mathrm{ml})$ was treated with $0 \cdot 1$ vols $3 \mathrm{M}$ $\mathrm{Na}$-acetate and $0 \cdot 8$ vols 2-propanol. DNA was spooled with a glass rod and then resuspended in $400 \mu$ distilled water.
RNA was removed by incubating the DNA solution for $2 \mathrm{~h}$ at $37^{\circ} \mathrm{C}$ with $50 \mu \mathrm{l}$ of an RNase cocktail $(3.3 \mu \mathrm{g}$ per $\mu \mathrm{l}$ RNase A $+3 \cdot 3 \mu \mathrm{g}$ per $\mu 1$ RNase B $+3 \cdot 3 \mu \mathrm{g}$ per $\mu \mathrm{l}$ RNase T1; Sigma).

Hydroxyapatite (HTP) purification. Since the accuracy of spectrophotometric measurement of DNA concentration is greatly affected by the presence of contaminants such as proteins and RNA (Springer \& Krajewski, 1989), a hydroxyapatite purification, allowing differential extraction of DNA and contamination with phosphate buffers of different concentrations (Purdy et al., 1996), is strongly recommended.

Hydroxyapatite HTP (100 mg; Bio-Rad) was suspended in $1 \mathrm{ml} 100 \mathrm{mM}$ sodium phosphate buffer (NPB) $\mathrm{pH} \mathrm{6.7}$, heated for $10 \mathrm{~min}$ at $65^{\circ} \mathrm{C}$ and centrifuged $(17000 \mathrm{~g})$ for $30 \mathrm{~s}$ at $4{ }^{\circ} \mathrm{C}$. After removal of the supernatant, the HTP pellet was resuspended with the DNA solution already equilibrated at $65^{\circ} \mathrm{C}$, incubated for $15 \mathrm{~min}$ at $65^{\circ} \mathrm{C}$ and then centrifuged $(17000 \mathrm{~g})$ for $30 \mathrm{~s}$ at $4{ }^{\circ} \mathrm{C}$. The HTP-bound DNA was then sequentially washed twice with $600 \mu \mathrm{l}$ $120 \mathrm{mM}$ NPB (pH 6.7) and once with $600 \mu 1180 \mathrm{mM} \mathrm{NPB}$ (pH 6.7). Finally, the HTP pellet was uniformly resuspended in $400 \mu \mathrm{l} 300 \mathrm{mM}$ potassium/sodium phosphate buffer (NPPB; $\mathrm{pH} 7 \cdot 2$ ) incubated for $15 \mathrm{~min}$ at $65^{\circ} \mathrm{C}$ and then centrifuged for $30 \mathrm{~s}$ at $17000 \mathrm{~g}$.

Desalination was carried out with a $1 \mathrm{ml}$ Sephadex G-50 (Sigma) spun column followed by ethanol-precipitation. DNA samples were read at 230, 260 and $280 \mathrm{~nm}$ with a Beckman DU-640 spectrophotometer to calculate the concentration and the level of purification. Finally, DNA samples were diluted in water to reach an optical density (at $260 \mathrm{~nm})$ of $0 \cdot 200 \pm 5 \%\left(=10 \mathrm{ng} \mu \mathrm{l}^{-1}\right)$ and stored at $-18^{\circ} \mathrm{C}$.

Dot-blot procedure. Nylon Hybond-N+ membranes (Amersham) were cut to the appropriate size $\left(1 \mathrm{~cm}^{2} /\right.$ sample), placed in a capillary blotter loaded with $100 \mathrm{ng}$ $(10 \mu 1)$ DNA solution per sample and dried for 5 min at room temperature. DNA was fixed with a 3 min exposure to a UV transilluminator $(302 \mathrm{~nm})$ and denatured by soaking the membrane for $3 \mathrm{~min}$ in $0.4 \mathrm{M} \mathrm{NaOH}$. After a brief wash in $2 \times$ SSC and air-drying, the membrane can be either used immediately or stored indefinitely at room temperature.

For quantitative experiments, a control serial dilution of unlabelled probe DNA corresponding to $100,80,60,40$ and $20 \mathrm{ng}$ was loaded on to the membrane to obtain an optical density versus signal calibration curve.

Probe DNA (100 ng) was denatured by boiling for $10 \mathrm{~min}$, cooled for $3 \mathrm{~min}$ in ice and then labelled using the ECLDirect (Amersham) non-radioactive procedure according to the manufacturer's instructions. Prehybridization, hybridization and high-stringency washings $(0.5 \% \mathrm{NaCl})$ were carried out at $42{ }^{\circ} \mathrm{C}$.

Densitometric analysis. X-ray films (Kodak X-OMAT) were exposed for the time required to avoid film saturation. The approximate time of exposure typically ranges from 2 to 5 min according to the shelf-life of the kit.

The calibration curve was obtained by plotting, on the $x$ axis, the values of the probe serial dilution and, on the $y$-axis, the corresponding signals expressed as the grey level on an 8bit system. The resulting regression equation was then used to calculate the reassociation level of each sample. Videodensitometric analysis was carried out with the free-domain 
package NIH-IMAGE version $1.62 \mathrm{~b}$ and densitometric data were processed with KALEIDA GRAPH (Synergy Software).

\section{RESULTS AND DISCUSSION}

The validation of the present method as a taxonomic tool was carried out by means of a series of experiments considering aspects directly involving (1) the optimization of labelling and hybridization procedures and development of an automated system for intensity reading of dots; and (2) the control of its performances in taxonomic working models previously certified by spectrophotometric DNA reassociation.

\section{Procedure optimization}

The ability of the ECL-Direct hybridization system to detect different amounts of DNA was checked as follows: 0, 20, 40, 60, 80 and $100 \mathrm{ng}$ DNA were blotted on to the same nylon membrane and then hybridized with $100 \mathrm{ng}$ of the same DNA labelled according to the ECL procedure described in the Methods. Results of this renaturation experiment (Fig. 1) show that there is a linear relationship between the DNA content and the signal generated, with a negligible level of error $(0.0288 \%)$. The same experiment was carried out with DNA from several yeast species, always obtaining linear regressions of similar quality (Table 1).

The consistent linearity and repeatability of the above results suggested that the actual amount of doublestranded DNA on each dot can be measured by videodensitometry.

To develop an internal control, a serial dilution of the same DNA used as probe was spotted on to each membrane to produce a calibration curve and the corresponding regression equation (Fig. 1).

Accordingly, membranes were prepared by spotting 100 ng DNA from each unknown culture together with a series of dots located in the lower part of the filter and carrying 0, 20, 40,60, 80 and $100 \mathrm{ng}$ of the same DNA used as the probe to produce the calibration curve. The rationale behind this loading arrangement is exemplified as follows: the intensity produced by the hybridization on the $80 \mathrm{ng}$ dot indicates $80 \%$ relatedness between the DNA of the unknown culture and that of the type strain of the species used as a probe. The hybridization is carried out overnight with $100 \mathrm{ng}$ labelled probe DNA, while spot intensities are determined video-densitometrically. These row data are introduced into the regression equation to obtain relatedness values (expressed as percentages).

\section{Use in a certified taxonomic context}

Selected samples of purified DNA (Table 2), in storage at $-20^{\circ} \mathrm{C}$ and already hybridized against the DNA of the type strain of Kluyveromyces lactis (DBVPG 6305 in the course of previous molecular taxonomic revisions (Vaughan-Martini \& Martini, 1987) carried out in this laboratory, were used to test the actual efficacy of the procedure.

The above hybridization tests were repeated using the proposed dot-blot procedure, with the DNA of the type strain of Saccharomyces cerevisiae (DBVPG $6173^{\mathrm{T}}$ ) as a probe (Fig. 2). Reassociation values from both approaches were reported on a plot and a regression curve was then calculated (Fig. 3). The $R^{2}$ value $(0.91)$ demonstrates a high and positive correlation between results obtained by the two radically different methods; the mean divergence was lower than the experimental error (approx. 10\%) observed in 20 years of spectrophotometric reassociations carried out in this laboratory (unpublished data).

An additional control experiment was done using another certified model consisting of two species, Saccharomyces castellii and Saccharomyces dairenensis, formerly classified as a single species but separated when DNA reassociation was applied (Vaughan-Martini \& Barcaccia, 1996; Vaughan-Martini \& Martini, 1988). Accordingly, a simulation was carried out using a certified strain of $S$. castellii (DBVPG 6361) as the unknown culture yet to be identified. Its DNA was hybridized against DNA from the type strains of $S$. castellii (DBVPG $6298^{\mathrm{T}}$ ) and $S$. dairenensis (DBVPG $6366^{\mathrm{T}}$ ), respectively.

The results (Fig. 4) show that there is only very poor homology between members of the two species when DNA from $S$. castellii is used; conversely, the two $S$. castellii strains gave identical results, in full accordance with the spectrophotometric results. Duplications of the above experiments, even with different DNA preparations, exhibited non-significant $(\leqslant 5 \%)$ differences.

One of the problems in microbial taxonomy is finding a 'gold standard' method for assigning, with certainty, an unknown strain to a species. There is a large body of evidence (Fuson et al., 1980; Scheda \& Yarrow, 1966, 1968) showing that some of the key characteristics used in conventional taxonomy may vary by a mere point mutation in their sequences. This can often produce an incorrect classification or merge species that are taxonomically distant. Moreover, conventional taxonomy takes into consideration a number of characteristics representing $\leqslant 3 \%$ of the whole informational capacity of the genome.

Using the same reasoning, most molecular taxonomic methods based on the migration ability of macromolecules cannot overcome the problems of considering an amount of information effectively representing the yeast genome, because normally only a few sequences are analysed with these techniques. For instance, a randomly amplified polymorphic DNA procedure with one primer producing 10 bands, of $2 \mathrm{~kb}$ average size, would give information on $20 \mathrm{~kb}$, which represents less than $1.5 \%$ of the whole genome of S. cerevisiae (Clayton et al., 1997; Mortimer et al., 1992). Taken together, these considerations lead to the 


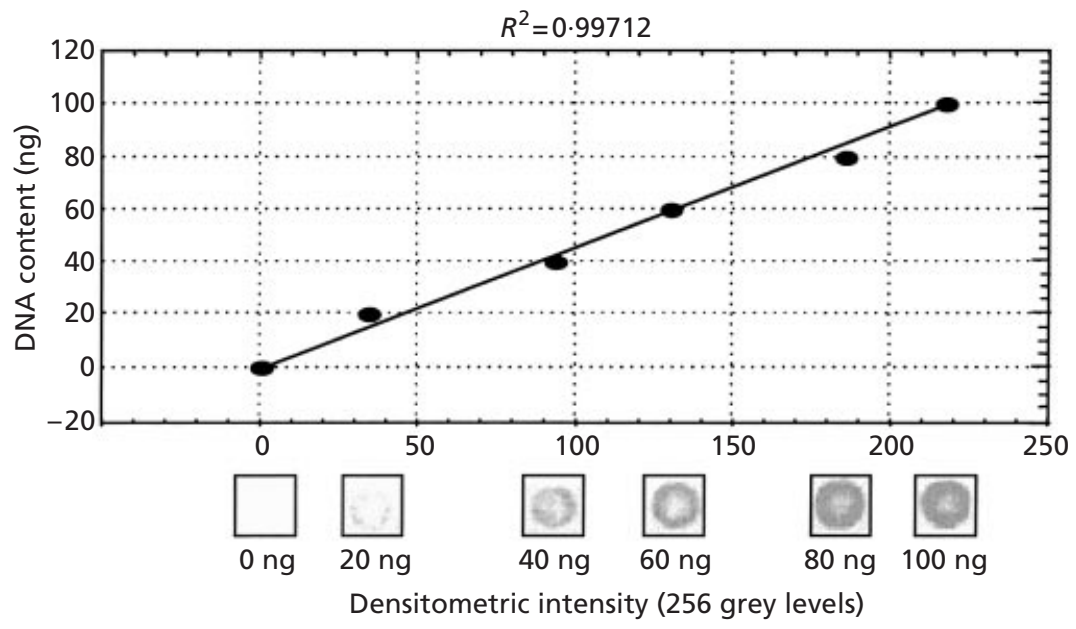

Fig. 1. Regression curve between densitometric intensity of dots and DNA content (DNA from Debaryomyces prosopidis DBVPG 7010').

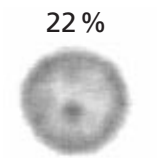

A

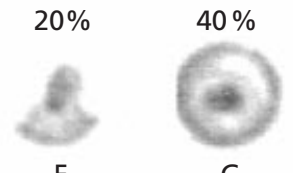

$\mathrm{F}$

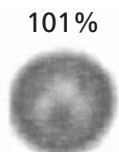

B

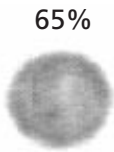

C

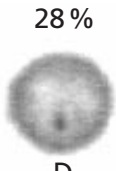

D

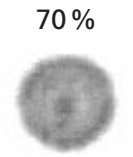

E

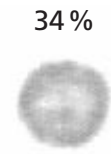

F

Fig. 2. Reassociation experiment between strains of different yeast species (see Table 2) and the type strain of Kluyveromyces lactis (DBVPG $6305^{\top}$ ). Numbers represent the percentage of calculated homology between the spotted DNA and that of the probe DBVPG $6305^{\top}$.

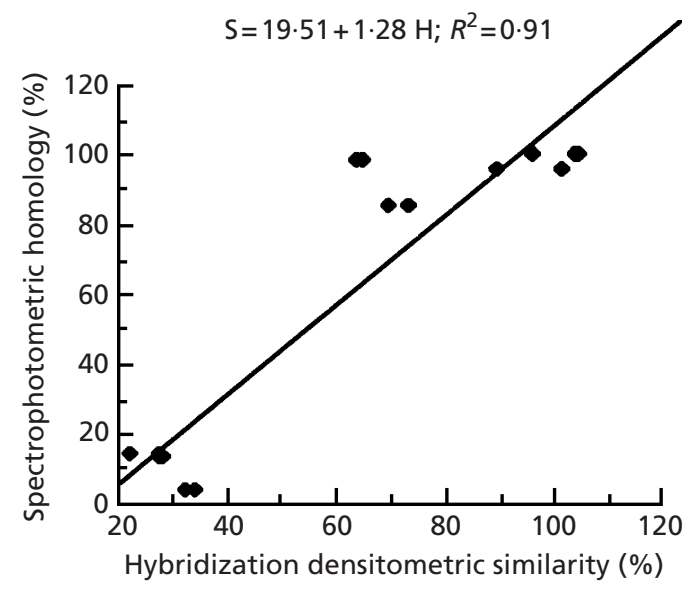

Fig. 3. Regression analysis, showing the relationship between the reassociation similarities of strains from different species with $K$. lactis DBVPG $6305^{\top}$ (see Fig. 2) according to the data obtained with spectrophotometric (S) and dot-blot hybridization $(\mathrm{H})$ procedures. An $R^{2}$ value of 0.91 indicates that the same reassociations carried out with two different methods yield strongly similar results.

conclusion that the method of choice should reflect the whole genome, as in the case of DNA-DNA reassociation.

The comparison of entire genomes automatically implies a lower resolution level for the analytical
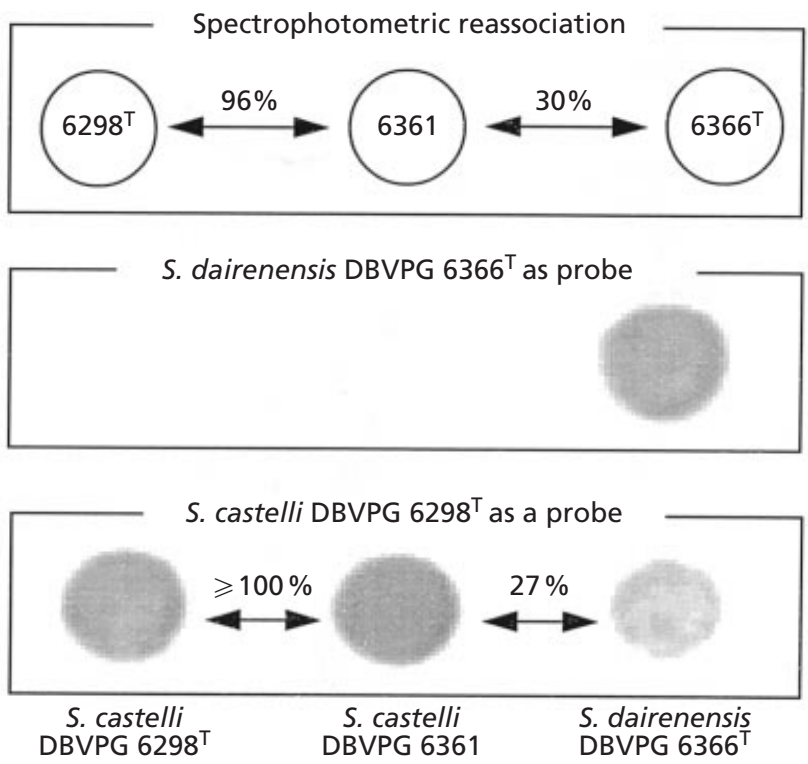

Fig. 4. Hybridization of Saccharomyces castellii strain DBVPG 6361 with the type strains of S. castellii (DBVPG $6298^{\top}$ ) and of $S$. dairenensis (DBVPG 6366 ${ }^{\top}$ ) with both the spectrophotometric procedure and the dot-blot procedure.

system; this cannot be accepted for typing at strain level, but does meet the requirements of classification at species level. 
According to the above considerations, the spectrophotometric reassociation technique has been considered as the ultimate taxonomic test in yeast systematics throughout the last two decades. However, it is a particularly time-consuming, expensive and cumbersome method. The method presented in this paper is mainly intended as a screening procedure when several strains have to be assigned to a yeast species.

In our experience, intermediate relatedness values (between 70 and $30 \%$ ) can often be due to technical problems (quality of DNA, precise quantification of target DNA, efficiency of labelling and detection kits) that can be addressed by improving the quality of the DNA and/or by testing the efficiency of the kits.

The impossibility of finding high levels of relatedness between an unknown strain and the type strain(s) of the species indicated by conventional taxonomy may also be ascribed to partial structural asymmetries of genomes (aneuploidy, different genome size, different amounts of strongly repeated sequences), which is something that can only be clarified by further molecular and taxonomic study.

Moreover, the blotting reassociation method can be used for better definition of the strains used as taxonomic models defining species and for producing a large number of cross results with a limited number of experiments. Finally, this procedure may be extended to produce more accurate analysis of the relationships between strains belonging to sibling or strongly related species.

\section{ACKNOWLEDGEMENTS}

This project was partly supported by grant ' $E x \quad 60 \%$ ' from the University of Perugia. G.L. was supported by the MURST Doctorate Programme grant.

\section{REFERENCES}

Bak, L. \& Stenderup, A. (1969). Deoxyribonucleic acid homology in yeasts. Genetic relatedness within the genus Candida. J Gen Microbiol 59, 21-30.

Barnett, J. A., Payne, R. W. \& Yarrow, D. (1990). Yeasts : Characteristics and Identification, 2nd edn. Cambridge: Cambridge University Press.

Clayton, R. A., White, O., Ketchum, K. A. \& Venter, J. C. (1997). The first genome from the third domain of life. Nature 387, 459-462.

Dutta, S. K., Richman, N., Woodward, V. W. \& Mandel, M. (1967). Relatedness among species of fungi and higher plants measured by DNA hybridization and base ratios. Genetics 57, 719-727.

Fuson, G. B., Price, C. W. \& Phaff, H. J. (1980). Deoxyribonucleic acid base sequence relatedness among strains of Pichia ohmeri that produce dimorphic ascospores. Int J Syst Bacteriol 30, 217-219.

Guého, E., Tredick, J. \& Phaff, H. J. (1985). DNA relatedness among species of Geotrichum and Dipodascus. Can J Bot 63, 961-966.

Hara, T., Shimoda, T., Nonaka, K. \& Ogata, S. (1991). Colorimetric detection of DNA-DNA hybridisation in microdilution wells for taxonomic application on bacteria strains. J Ferment Bioeng 72, 122-124.

Kurtzman, C. P. (1990a). DNA relatedness among species of Sterigmatomyces and Fellomyces. Int J Syst Bacteriol 40, 56-59.

Kurtzman, C. P. (1990b). DNA relatedness among species of the genus Zygosaccharomyces. Yeast 6, 213-219.

Kurtzman, C. P. \& Fell, J. (1998). The Yeasts : a Taxonomic Study, 4th edn. Amsterdam: Elsevier.

Kurtzman, C. P., Phaff, H. J. \& Meyer, S. A. (1983). Nucleic acid relatedness among yeasts. In Yeast Genetics-Fundamental and Applied Aspects, pp. 139-166. Edited by J. F. T. Spencer, D. M. Spencer \& A. R. W. Smith. New York: Springer.

Kurtzman, C. P., Smiley, M. J., Robnett, C. J. \& Wicklow, D. (1986). DNA relatedness among wild and domesticated species of the Aspergillus flavus group. Mycologia 78, 955-959.

Lee, C. F., Lee, F. L., Hsu, W. H. \& Hsu, W. H. (1993). DNA reassociation and electrokaryotype study of some Candida species and synonymy of Candida terebra, Candida entomaea, and Candida veronae. Can J Microbiol 39, 863-867.

Lockhart, W. R. (1967). Factors affecting reproducibility of numerical classifications. J Bacteriol 94, 826-831.

Martini, A. \& Phaff, H. J. (1973). The optical determination of DNA-DNA homologies in yeasts. Ann Microbiol 23, 59-68.

Meyer, S. A. (1970). DNA Base Composition and DNA-DNA Homology Studies as Tools in Yeast Systematics. Davis: Bacteriology Department, University of California.

Meyer, S. A. \& Phaff, H. J. (1972). DNA base composition and DNA-DNA homology as tools in yeast systematics. In Yeast Models in Science and Technology, pp. 375-387. Edited by A. Kocková-Kratochvilová \& E. Minárik. Bratislava, Slovakia: Slovak Academy of Science.

Meyer, S. A., Anderson, K., Brown, R. E., Smith, M. T., Yarrow, D., Mitchell, G. \& Ahearn, D. G. (1975). Physiological and DNA characterization of Candida maltosa, a hydrocarbon-utilizing yeast. Arch Microbiol 104, 225-231.

Meyer, S. A., Brown, R. E. \& Smith, M. T. (1977). Species status of Hanseniaspora guilliermondii Pijper. Int J Syst Bacteriol 27, 162-164.

Mortimer, R. K., Contopoulou, C. R. \& King, J. S. (1992). Genetic and physical maps of Saccharomyces cerevisiae, Edition 11. Yeast 8, 817-902.

Ouchi, K., Saito, H. \& Ikeda, Y. (1970). Genetic relatedness of yeast strains studied by the DNA/DNA hybridization method. Agric Biol Chem 34, 95-101.

Purdy, K. J., Embley, T. M., Takii, S. \& Nedwell, D. B. (1996). Rapid extraction of DNA and rRNA from sediments by a novel hydroxyapatite spin-column method. Appl Environ Microbiol 62, 3905-3907.

Scheda, R. \& Yarrow, D. (1966). The instability of physiological properties used as criteria in the taxonomy of yeasts. Arch Mikrobiol 55, 209-225.

Scheda, R. \& Yarrow, D. (1968). Variation in the fermentative pattern of some Saccharomyces species. Arch Microbiol 61, 310-316.

Springer, M. \& Krajewski, C. (1989). DNA hybridization in animal taxonomy: a critique from first priciples. $Q$ Rev Biol 64, 291-318.

Vaughan-Martini, A. (1991). Evaluation of phylogenetic relationships among fission yeasts by $\mathrm{nDNA} / \mathrm{nDNA}$ reassociation and conventional taxonomic criteria. Yeast 7, 73-78.

Vaughan-Martini, A. \& Barcaccia, S. (1996). A reconsideration of 
species related to Saccharomyces dairensis (Naganishi). Int J Syst Bacteriol 46, 313-317.

Vaughan-Martini, A. \& Martini, A. (1987). Taxonomic revision of the genus Kluyveromyces by nuclear deoxyribonucleic acid reassociation. Int J Syst Bacteriol 37, 380-385.

Vaughan-Martini, A. \& Martini, A. (1988). Deoxyribonucleic acid relatedness among species of Saccharomyces sensu lato. Mycologia 80, 241-243.

van der Walt, J. P. \& Johannsen, E. (1979). A comparison of interfertility and in vitro DNA-DNA reassociation as a criteria for speciation in the genus Kluyveromyces. Antonie Leeuwenhoek 45, 281-291. 